\title{
Influence of Nitrogen and Potassium Fertilization Levels on the Population Density of the Bird Cherry - Oat Aphid, Rhopalosiphum padi Linnaeus (Homoptera: Aphididae). Awadalla, S. S. 1 ; S. B. Beleh ${ }^{2}$ and Mohsena R. K. Mansour ${ }^{2}$. \\ 1 Economic Entomology Department, Faculty of Agriculture, Mansoura University, Mansoura, Egypt \\ 2 Field Crop Insect Pest Department, Plant Protection Research Institute, Agricultural Research Center, Sakha, Egypt
}

\begin{abstract}
The experiments were carried out in the experimental farm of Sakha Agricultural Research Station, Kafr El - Sheikh Government during two successive seasons, 2013/14 and 2014/15. This study was carried out to determine the relationship between rates of $\mathrm{N}$ and $\mathrm{K}$ Fertilization on the average number of the bird cherry - oat aphid, Rhopalosiphum padi attacking wheat. The obtained results showed that, $R$. padi population increased significantly by increasing the rate of nitrogen fertilizer (Nitrates 33.5\%). the average numbers of $R$. padi on wheat during the two successive seasons . The highest average number of $R$. padi was recorded on nitrogen rates of $200 \mathrm{Kg}$ with an average of $342.5 \pm 95.7$ and $236.2 \pm 56.9$ indiv.respectively. While, the lowest average number of aphid was recorded on nitrogen rates of $0 \mathrm{Kg}$ with an average of $259.4 \pm 79.4$ and 179.7 \pm 47 .6indiv. respectively. Statistical analysis during the two seasons indicated significant differences between the aphids' and $\mathrm{N}$ rates on wheat. The results indicated that increasing potassium fertilization level from 25 to $75 \mathrm{Kg} / \mathrm{fed}$. Caused a significantly decreasing in the average number of $R$. padi during the first season while the second season was in significantly. the highest average number of $R$. padi was recorded on the first level of potassium fertilization with an average number of $213.2 \pm 64.7$ and $170.8 \pm$ 52.1 indiv.respectively. While, the lowest average number of aphid was recorded on the four level of potassium with an average of $154.1 \pm 48.3$ and $123.1 \pm 36.8$ indiv.respectively.
\end{abstract}

Keywords: Aphids, Fertilization, Wheat.

\section{INTRODUCTION}

Wheat (Triticum aestivum L.) is the most important grain crop all over the world. (Anwar et al.2009).It is the main winter cereal crop which gained a particular importance for human consumption According to the Food and Agriculture Organization of the United Nations (FAO 2012). Aphid species are considered as one of the most serious pests attacking wheat causing damage to the plants either directly by sucking juice or indirectly as a vector of diseases, (Zia, et al. 2010). Yield losses due to infestation with aphids differed from 7.5 to $18.7 \%$ (El- Rawy, 2013).

Fertilization is an important agronomic strategy used extensively to increase crop yield. Although the effects of fertilizers are extensively investigated in wheat, there is little information to assess the effect of fertilizer application on wheat. While, the population density and the average number of the main aphid species especially $R$. padi, affected significantly with different rates of fertilizations (Youssef, 2006 and Al Habashy, 2008). On the other hand, from the available literature some authors have studied the relationship between nitrogen fertilizer level and aphids' infestation and increasing nitrogen level causes increase in the infestation rate with this insect pest (Draz et al. 2013). From the essential components of pest management programs are fertilization levels the nitrogen as well as potassium.(Bi, et al. 2003; ElZahi, et al. 2012 and Saleh, et al. 2016).

The present study aimed to throw the light on the effect of different nitrogen and potassium levels on the population density and average numbers of the main aphid species to serve as a basis for the use of this information's in integrate pest management programs.

\section{MATERIALS AND METHODS}

The experiments were carried out in the experimental farm of Sakha Agricultural Research
Station, Kafr El - Sheikh Government during two successive seasons, 2013/14 and 2014/15. This study was carried out to determine the relationship between rates of NPK Fertilization on the average number of $R$. padi on wheat crop.(variety Sids12). Seeds for each were sown in the third planting date, (Beginning of December) for the two successive seasons and the experimental area was about $1600 \mathrm{~m}^{2}$. The area was divided to 32 replicates, each replicate was about $50 \mathrm{~m}^{2}$ and the replicates arranged in Completely Randomized Design, and for each fertilization treatment 4 replicates were used.

The rates of nutrient elements were tested as follow : - To evaluate the effect of nitrogen fertilization on $R$. padi, four rates of nitrogen (Urea nitrate 33.5\%) 0, 90, 150 and $200 \mathrm{Kg}$ per Fadden were used and the rate of phosphorus (ph205 15\%) and the rate of Potassium (K2O 24\%) was applied.

- To evaluate the effect of potassium fertilization on $R$. padi, four rates of (potassium sulphate $24 \% \mathrm{k} 2 \mathrm{o}$ ) 0 , 25,50 and $75 \mathrm{Kg}$ per Fadden were used and the rate of phosphorus (ph2O5 15\%) and the rate of nitrogen (N $33.5 \%$ ) was applied.

-The quantity of fertilizers was added to plants at three equal times for nitrogen, the first of the quantity was added with plantation, the second one with the first irrigation and the third rate with the second irrigation. While phosphate and potassium were used all quantity with plantation .Pesticides treatment was avoided completely. The weekly examination was started from adding NPK fertilizer and continued until harvest. During two successive seasons number of $R$. padi was counted on 20 plants.

\section{RESULTS AND DISCUSSION}

\section{Effect of nitrogen:}

The main purpose of this study was to determine the relationship between fertilization of wheat plants by nitrogen rates $(0,90,150$ and $200 \mathrm{Kg})$ and constant rate 
of phosphorus fertilization P2O5 15\% (200 Kg/fed.) on $R$. padi wheat plants during the two successive seasons. Data represented in Fig. (2) Showed that the total numbers and their ratios of $R$. padi, during the two seasons. Nitrogen rates of $200 \mathrm{Kg}$ attractived the highest numbers and ratio of $R$. padi during the two seasons and represented by $5822 \quad(28 \%)$ and 4016indiv.(28\%) respectively. While, Nitrogen rates of $0 \mathrm{Kg}$ attractived the lowest number and ratio of $R$. padi during the two seasons and represented by $4410(21 \%)$ and 3055 indiv. $(22 \%)$ respectively.

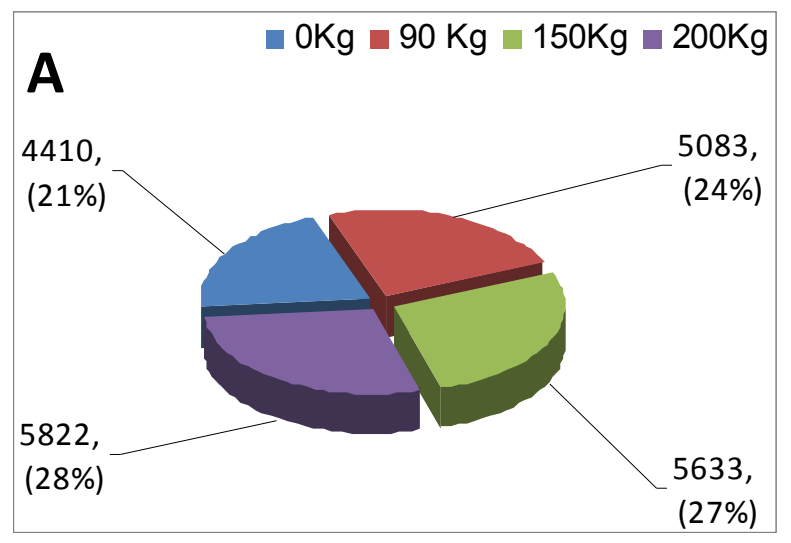

B

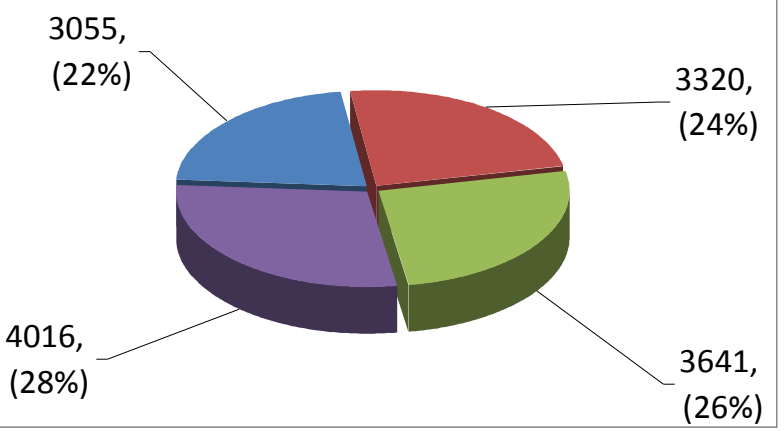

Fig 1. Total number and their ratios of $R$. padi on different rates of $N$ during the two successive seasons 2013/14 (A) and 2014/15 (B) at Kafr ElSheikh Governorate.

Data presented in Table (1) showed the average numbers of $R$. padi on wheat during the two seasons. The highest average number of $R$. padi was recorded on nitrogen rates of $200 \mathrm{Kg}$ with an average of $342.5 \pm$ 95.7 and $236.2 \pm 56.9 \mathrm{indiv}$. respectively. While, the lowest average number of aphid was recorded on nitrogen rates of $0 \mathrm{Kg}$ with an average of $259.4 \pm$ 79.4and $179.7 \pm 47$.6indiv.respectively.

As a conclusion, date presented in table (1) and illustrated in fig. (1) Showed that $R$. padi population increased significantly by increasing the rate of nitrogen fertilizer (Nitrates 33.5\%). The seasonal numbers of aphid were 5822 and 4016indiv.with $\mathrm{N}$ fertilization at $200 \mathrm{~kg}$ of nitrogen fertilizer by adding nitrogen fertilizer at the rates of $0.90,150$ and $200 \mathrm{Kg}$ /feddan, respectively. Statistical analysis during the two seasons indicated significant differences between the aphids' and $\mathrm{N}$ rates on wheat plant.
These results are in agreement with those of Nevo and Coll., (2001). El- Zahi, et al., (2012).Draz, et al. (2013).The mentioned that, the effect of different rates of Nitrogen $(\mathrm{N})$ fertilizer $(80,120,160$ and $200 \mathrm{~N}$ units/feddan) on population density of piercing sucking insect pests was also concerned on tomato plants. Rates of nitrogen fertilizer showed high significant effect on populations' densities for each of $B$. tabaci nymphs, $E$. decipiens and T.tabaci. Where, rates of 80 and 120 units of nitrogen fertilizer showed lowest level of population densities for those pests .On contrary rates of nitrogen fertilization hadn't any significant effect on population's density of $A$. gossypii. So it recommended not increasing rates of $\mathrm{N}$ fertilization to levels higher than 120 unite/feddan at tomato fields. Khorchid (2013) showed that the aphids' population (R.padi and $S$. graminum) on Giza 168 wheat variety was more susceptible to aphid infestation with fertilization at 150 units of nitrogen fertilizer. On the other hand, the wheat plants which were treated by 90 units of nitrogen fertilizer, the infestation of aphids was the lowest value.

Table 1. Influence of rates of $N$ on the average numbers of $R$. padi on wheat plants during 2013/14 and $2014 / 15$ seasons .

\begin{tabular}{lccc}
\hline Rates of N. & $\begin{array}{c}\mathbf{2 0 1 3} / \mathbf{1 4} \\
\text { season }\end{array}$ & $\begin{array}{c}\mathbf{2 0 1 4} / \mathbf{1 5} \\
\text { season }\end{array}$ & Av. \pm SE \\
\hline $0 \mathrm{Kg}$ & $259.4 \pm 79.4 \mathrm{c}$ & $179.7 \pm 47.6 \mathrm{~b}$ & $219.6 \pm 63.5$ \\
$90 \mathrm{Kg}$ & $299.0 \pm 90.9 \mathrm{~b}$ & $195.3 \pm 50.8 \mathrm{a}$ & $247.2 \pm 70.9$ \\
$150 \mathrm{Kg}$ & $331.4 \pm 98.2 \mathrm{a}$ & $214.2 \pm 55.1 \mathrm{a}$ & $272.8 \pm 76.7$ \\
$200 \mathrm{Kg}$ & $342.5 \pm 95.7 \mathrm{a}$ & $236.2 \pm 56.9 \mathrm{a}$ & $289.4 \pm 76.3$ \\
LSD at 5\% & 6.4 & 4.3 & \\
\hline
\end{tabular}

In a column, means followed by the same letter are not significantly different at the $5 \%$ level

Effect of Potassium:

The main purpose of this study was to determine the relationship between rates of $\mathrm{K}$ fertilization on R.padi on wheat plants by potassium sulphate $24 \%$ rates $(0,25,50$ and $75 \mathrm{Kg})$ and constant rates of nitrogen fertilizer (150 Kg/ fed.) and phosphorus (200 Kg/fed.) wheat plants during the two seasons. Data represented in Fig.(2) Showed that the total numbers and their ratios of $R$. padi, The highest numbers and ratio of $R$. padi during the two successive seasons in first level and represented by $3624(28 \%)$ and 2904indiv.(28\%) respectively. While, the lowest number and ratio of $R$. padi in the four level of potassium and represented by 2620(21\%) and 2093indiv.(20\%) respectively.

Data presented in Table (2) showed the average numbers of $R$. padi on wheat during the two successive seasons. According to the highest average number of $R$. padi was recorded on the first level of potassium fertilization with an average number of $213.2 \pm 64.7$ and $170.8 \pm 52.1$ indiv.respectively.

Table 2. Influence of rates of $K$ on the average numbers of $R$. padi on wheat plants during $2013 / 14$ and $2014 / 15$ seasons.

\begin{tabular}{|c|c|c|c|}
\hline $\begin{array}{l}\text { Rates of } \\
\text { K. }\end{array}$ & $\begin{array}{c}2013 / 14 \\
\text { season }\end{array}$ & $\begin{array}{c}2014 / 15 \\
\text { season }\end{array}$ & Av. \pm SE \\
\hline$\overline{0 \mathrm{Kg}}$ & $213.2 \pm 64.7 \mathrm{a}$ & $170.8 \pm 52.1 \mathrm{a}$ & $192.0 \pm 58.4$ \\
\hline $25 \mathrm{Kg}$ & $201.4 \pm 62.8 \mathrm{a}$ & $169.2 \pm 52.1 \mathrm{a}$ & $185.3 \pm 57.5$ \\
\hline $50 \mathrm{Kg}$ & $179.4 \pm 55.5 \mathrm{a}$ & $153.6 \pm 46.9 a$ & $166.5 \pm 51.2$ \\
\hline $75 \mathrm{Kg}$ & $154.1 \pm 48.3 b$ & $123.1 \pm 36.8 \mathrm{a}$ & $138.6 \pm 42.6$ \\
\hline LSD at $5 \%$ & 5.8 & 5.3 & \\
\hline
\end{tabular}


While, the lowest average number of aphid was recorded on the four level of potassium with an average of $154.1 \pm 48.3$ and $123.1 \pm 36.8$ indiv.respectively.
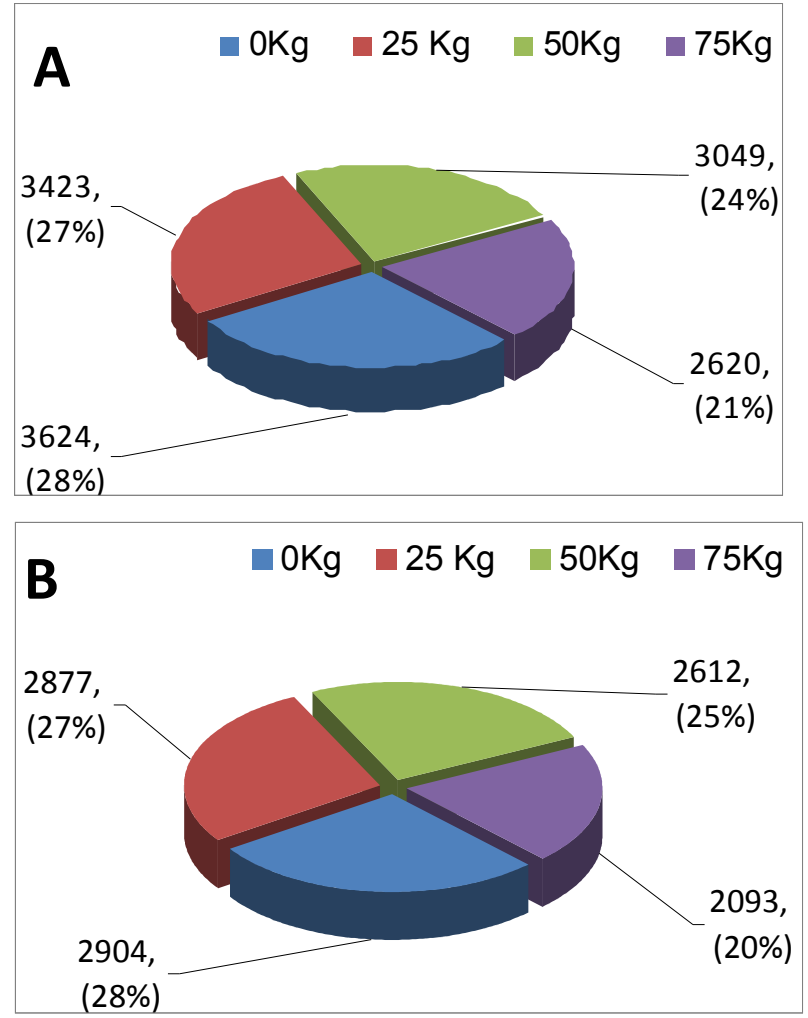

Fig 2. Total number and their ratios of $R$. padi on different rates of $K$ during the two successive seasons 2013/14 (A) and 2014/15 (B) at Kafr El- Sheikh Governorate.

As a conclusion, the highest mean numbers of insects per sample occurred with control (without potassium fertilization) whereas the lowest population density of these insects recorded with $75 \mathrm{~kg}$ of potassium /feddan increasing potassium fertilization level from 25 to $75 \mathrm{Kg} / \mathrm{fed}$. Caused a significantly decreasing in the average number of $R$. padi during the first season while the second season was in significantly.

These results are in agreement with those of (Hegab, 2001; Youseef, 2006; El- Gindy, 2002; Al Habashy, 2008 and Saleh, et al. 2016). They mentioned that effect of different rates of $\mathrm{N} \& \mathrm{~K}$ fertilizations on wheat plants on population density of aphid insects on wheat plants the highest mean numbers of insects per sample occurred with control (without potassium fertilization) whereas the lowest population density of these insects recorded with 36 unit of potassium /feddan

\section{REFERENCES}

Alsahary, I. (2014). FAO: Wheat production to decline by $2 \%$ in 2014. Retrieved from Egypt independent.com/news/fao-wheat-productiondecline-2.

EL-Rawy. A. M. (2013): susceptibility of certain wheat cultivars to infestation with cereal aphids and glassy clover snails. Egypt. J. Agric. Res., 91 (2) 551-559.

Al- Habashy, A. Z. N. (2008). Studies on certain insects pests infesting some graminaceous field crops. Ph. D. Thesis. Fac. Agric, Benha, univ., 204 pp.

Anwar, J; M.A. Ali; M. Hussain; W. Sabir; M.A. Khan; M. Zulkiffal and M. Abdullah, (2009). Assessment of yield criteria in bread wheat through correlation and path analysis. J. Animal and Plant. Sci., 19: 185-188.

Bi, J. L; N. C. Toscano, and M. A. Modare, (2003).Effect fertilizer application on salable protein and free amino acid content of cotton petioles in relation to me silver leaf whitefly Bemisia Argentifolii, population. J. Chem. Ecol. 29(3): 747-761.

Draz, A. A. K; A. E. A. Darwish, and M. M. R. Tabikha (2013). Effect of different rates of Nitrogen fertilizer on infestation level with piercing sucking pests of tomato crop, Lycopersicon esculentum L.J. Agric. Env. Sci. Dam. Univ., Egypt. 12 (3): $20-32$.

El- Gindy, M. A. (2002): Studies on certain homopterous insect vectors of plant pathogenic diseases. Ph.D of Thesis Fac. Agric. Zagazig Univ.

El-Zahi, E. S.; S. A. Arif; B. A. E. Jehan ; E. H. E. Madeha (2012). Inorganic fertilization of cotton field-plants in relation to sucking insects and yield production components of cotton plants. The Journal of American Science; 8(2): 509-517.

Hegab-Ola, I. M. S. (2001): Studies on certain insect vectors of plant pathogenic agents. Ph. D. of Science. Fac. Agric. Zagazig Univ.

Khorchid , A.M. A. H.(2013): Studies on some wheat pests and their control. Ph. D. Thesis. Fac. Agric., Benha univ., $252 \mathrm{pp}$.

Nevo, E; and M. Coll (2001). Effect of nitrogen fertilization on Aphis gossypii (Homoptera : Aphididae) variation in size color, and reproduction, J.Econ. Entomology; 94, 27-32.

Saleh, A.A.; L. R. EL-Gohary; A. M. Hamed, and R. I. Baz;(2016). Effect of Nitrogen fertilization doses of cotton crop insects and their certain associated predators. J. Plant Prot. And Path., Mansoura Univ., 7(3):183-191.

Youssef, A. A. A. (2006): Studies on some homopterous insect vectors of plant diseases. ph. D. Thesis, Fac. Agric., Zagazig Univ.

Zia, A., S.A. Hassan, A. Shehzad and F. Naz, (2010).Diversity of Aphidoidea in Rawalpindi Division (Punjab) Pakistan, with a list of host plant studied. Halteres, 1: 40-46.

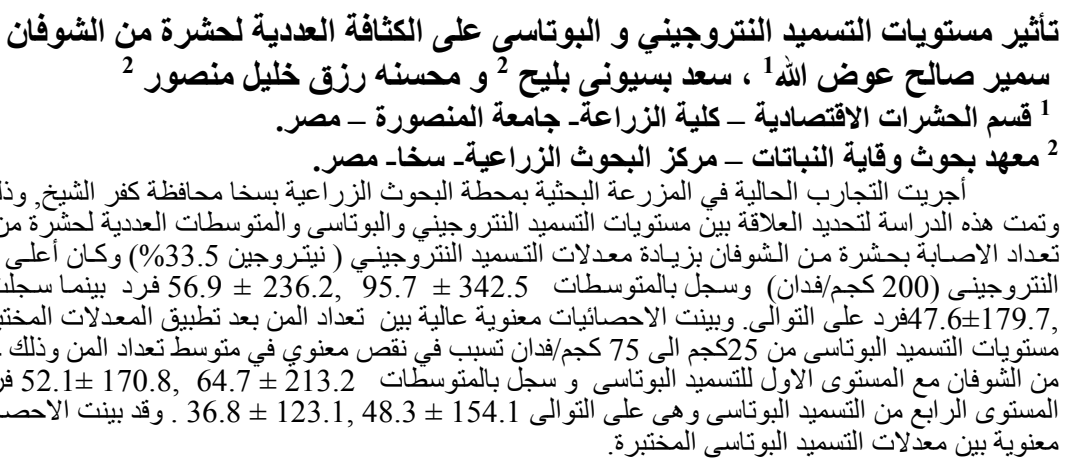

